\title{
Ping River Palaeochannels: A Review of Evidence across Historical Literature, Archaeology and Geoscience
}

\author{
Elisha Anne Teo ${ }^{1,2}$ \\ ${ }^{1}$ Department of Geography, National University of Singapore, Singapore \\ 117570 \\ ${ }^{2}$ Asian School of Environment, Nanyang Technological University, Singapore \\ 639798
}

Corresponding author. E-mail: elishaanneteo@gmail.com

https://doi.org/10.12982/CMUJASR.2018.0001

\section{ABSTRACT}

There is evidence that the Ping River in the Chiang Mai Basin, Thailand, has experienced multiple avulsions in the past. However, the history and the development of these avulsions remain largely unclear. Such knowledge, vital for river and disaster management, is important because a future avulsion would be catastrophic for the local population. This paper summarises, updates and reviews evidence of Ping River palaeochannels/avulsions across currently published historical literature, archaeology and geoscience. The author's own preliminary observations and findings from the present landscape are also shared. Through this review, it is learnt that there are at least six palaeochannels in the Chiang Mai Basin, that a large flood had triggered at least one avulsion, and that human influence must be considered when interpreting the avulsion record. However, there are still significant uncertainties and knowledge gaps due to 1) intense basin surface modification, 2) unknown palaeochannel ages, and 3) uncertain avulsion mechanisms for all palaeochannels. Such information needs to be resolved in future research.

Keywords: Palaeochannels, Avulsions, History, Ping River, Flood, Literature, Archaeology, Sedimentology 


\section{INTRODUCTION}

A river avulsion occurs when streamflow breaches its channel and is diverted towards another trajectory, eventually forming a new channel belt that may or may not re-join its parent channel further downstream (Allen, 1965; Bridge \& Leeder, 1979; Jones \& Schumm, 1999; Makaske, 2001). Avulsions generally occur because the original parent channel has become unstable, too inefficient to transport its streamflow and sediment load, and so a new efficient course is sought and formed (Jones \& Schumm, 1999; Makaske, 2001; Slingerland \& Smith, 2004; Kleinhans et al., 2008; Carling et al., 2014). The remnant of an abandoned parent channel is known as a palaeochannel. Avulsions can be catastrophic in populated areas, as they can lead to prolonged flooding and drainage issues, leading to loss of life and significant damage (Qian, 1990; Slingerland \& Smith, 2004; Sinha, 2009; Chakraborty et al., 2010). In an avulsion, the instability of the parent channel means that water is 'displaced' more persistently than in a flood, as water may not easily return to its fluvially inefficient parent channel. Recent avulsion disasters such as the 2010 Indus River and the 2008 Kosi River avulsions call for increased appreciation of the geomorphic processes involved with avulsion development (Sinha, 2009; Syvitski \& Brakenridge, 2013).

There is evidence that the Ping River in the Chiang Mai Basin, Thailand, is an avulsing river. However, an avulsion has not occurred within living memory (i.e. an avulsion has not been witnessed by those who are now alive), and so information of past avulsions is contained to what has been discovered through historical studies, including within literature, archaeology and geoscience. Oral history from the local population is very limited, diminished through the passage of time (Teo, 2018). The nature of avulsions along the Ping River remains largely unclear - why and how often do avulsions occur, and what is the likelihood of a future avulsion? Another avulsion in the present landscape would be catastrophic since the entire Chiang Mai Basin is now settled.

River and disaster management lessons from other avulsing systems will not be sufficient because local knowledge is crucial for understanding specific avulsing systems and their appropriate management (Phillips, 2011). To begin with, the current literature on palaeochannels/avulsions in the Chiang Mai Basin needs to be reviewed. This paper summarises, updates and reviews evidence of Ping River 
palaeochannels/avulsions across published historical literature, archaeology and geoscience. The author's own observations and findings from the present landscape are also shared. Information gleaned from existing historical studies can offer insight and help formhypotheses for future research to proceed. Pieces of information sought include: 1) what are the known palaeochannels, 2) when did these avulsions occur, and 3) why did these avulsions occur?

\section{STUDY SITE}

The Chiang Mai Basin (Figure 1) is an intermontane basin of the basin and range landscape of Northern Thailand (Macdonald et al., 1993). On either side of the Basin, there are mountain ranges with maximum elevations of $1,685 \mathrm{~m}$ in the west and 1,025 $\mathrm{m}$ in the east. The Basin itself is relatively flat, lying between 280 and $360 \mathrm{~m}$ above sea level (Margane \& Tatong, 1999). The entire Basin is settled and in use. Urbanisation and population density is highest around Chiang Mai and Lamphun. An estimated 241 villages are spread across the remainder of the Basin (Tongsa-ard, 1988), many of which cultivate rice and fruit. Since the mid-20 $0^{\text {th }}$ Century, the Chiang Mai Basin has experienced significant urbanisation (McGrath et al., 2017). The Chiang Mai Basin was rich with forests until the $19^{\text {th }}$ Century (Van Beek, 1995; Promsao, 1996).

The largest river in the Basin is the Ping River, a major tributary of the Chao Phraya River system. In total, the Ping River is $658 \mathrm{~km}$ long; within the Basin, the river is $\sim 115 \mathrm{~km}$. In the study area, the river is predominantly a single-channel sand-bed river with low sinuosity, and its width ranges between 70 to $110 \mathrm{~m}$. Over a 90-year instrumental record, the average annual peak discharge is $\sim 400 \mathrm{~m}^{3} \mathrm{~s}^{-1}$ (Lim et al., 012). The Kuang River is a major tributary of the Ping River (Figure 1). 


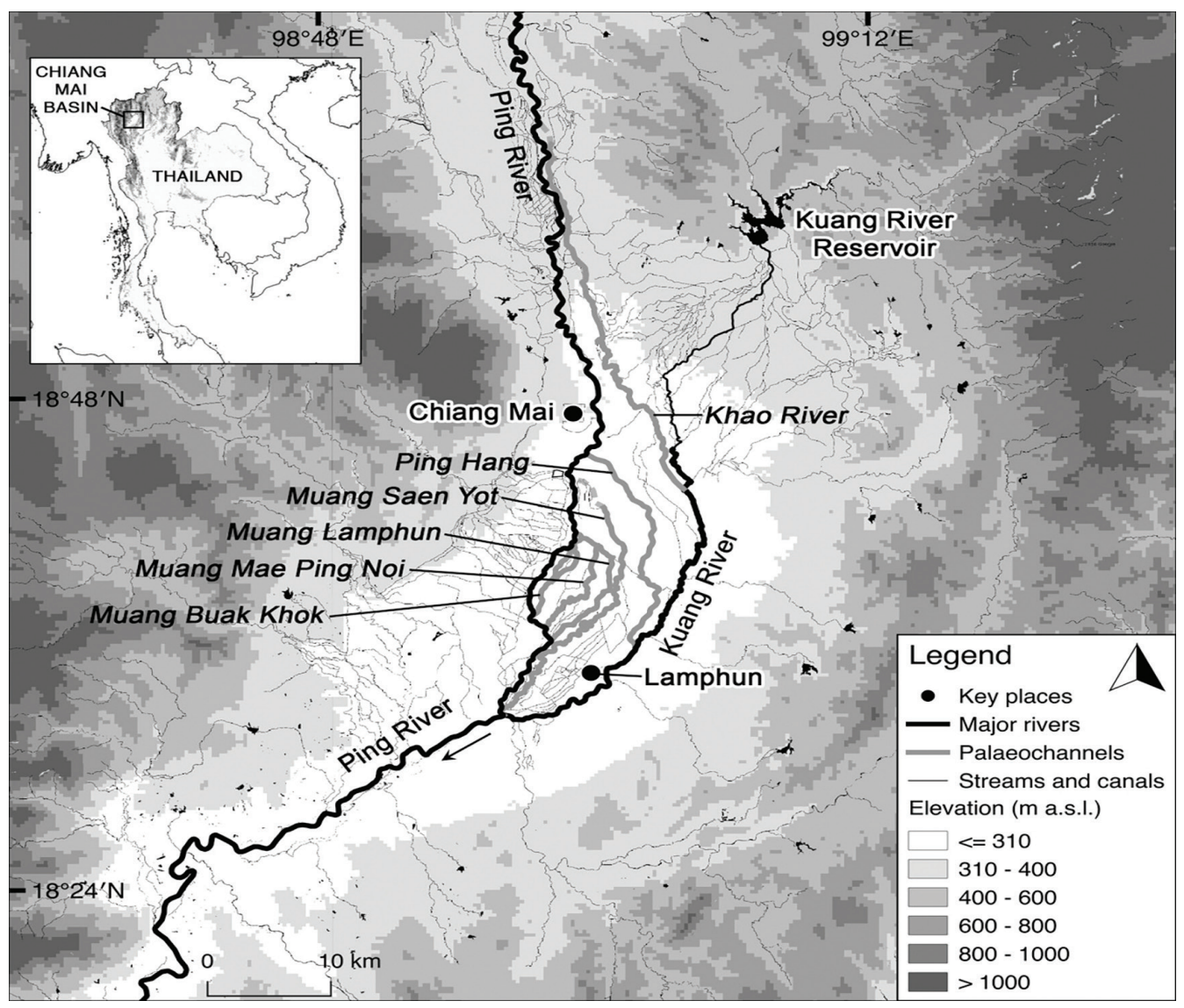

Figure 1. The Chiang Mai Basin is an intermontane basin in Northern Thailand (see inset). Major rivers (see thick black lines) include the Ping River and its tributary, the Kuang River. Flow direction is from north to south. Palaeochannels (abandoned, mostly dry, river channels) discussed within this paper are also shown (see thick grey lines; their names in italics).

\section{MATERIALS AND METHODS}

Evidence of palaeochannels is sourced from historical literature, past archaeological studies, past geoscientific studies, and the author's own map analysis and preliminary fieldwork. Evidence is presented by the following subdivisions: 1) palaeochannels visible by settlement patterns and irrigation canals, 2) the Ping Hang palaeochannel, and 3 ) the Khao River palaeochannel. In the discussion section of this paper, knowledge contributions and gaps are identified from the collated information. 
In most Thai literature, years are presented in Buddhist Era. This paper subtracts 543 years from all Buddhist Era years to convert them into the Common Era (CE) system. Thai publications originally published using the Buddhist Era convention are also cited in Common Era. An index of translated Thai names is provided for clarity due to mixed transliteration and Romanisation practices in the literature (Appendix A). Some rivers/places/historical texts also have multiple names. Whenever possible, the most commonly used translations are adopted (e.g. most place/river names are consistent with those published in Google Maps/Earth), though this produces some Romanisation inconsistencies with other sources that are resolvable using Appendix A.

\section{EVIDENCE OF PALAEOCHANNELS}

Palaeochannels visible by settlement patterns and irrigation canals

As early as the Lanna civilisation ( $13^{\text {th }}$ to $18^{\text {th }}$ Century), rivers have played an important role in the lives of the Northern Thai population. Extensive wet-rice cultivation required the Lanna to settle in areas close to rivers for irrigation, transport and trade. Rivers were vital for defence and communication (Ongsakul, 2005). Due to Theravada Buddhism and local animism influences, settlement near rivers was also believed to be auspicious (Penth, 2004; Ng et al., 2015). At the same time, vicinity to rivers exposed locals to floods. Local villagers traditionally adapted to living in the floodplain via architectural strategies, such as by building on higher ground (e.g. upon natural levees), by building elevated stilt houses, or by building floating houses ( $\mathrm{Ng}$ et al., 2015).

The significance of rivers is reflected in the settlement patterns of Northern Thailand, in the linear pattern and clusters of settlement along rivers and streams (Srisaka, 1989). The remnants of this older settlement pattern are still evident in the Chiang Mai Basin today (albeit increasingly concealed by urbanisation, which is less influenced by the traditional attachment to rivers; Van Beek, 1995; Lebel et al., 2010). King Mengrai founded the city of Chiang Mai along the western bank of the Ping River in 1296 CE (Figure 1). Throughout the Chiang Mai Basin, villages, temples and major roads are found upon levees parallel to rivers and major streams (Cohen \& Pearson, 1998). Paddy fields, many of which converted into orchards in the 1980s (McGrath et al., 2017), were established in slackwater areas and receive irrigation from the rivers (Surarerks, 2006). 
According to Tongsa-ard (1988), Ping River palaeochannels are apparent from the settlement patterns within the Chiang Mai Basin. Throughout the Basin, several meandering strands of villages can be found, several metres higher in elevation than the wide expanses of paddy fields and orchards between, giving the impression that these villages were once built upon the levees of meandering rivers (Figure 2a). However, there are no active rivers adjacent to these villages today. It was proposed that these meandering settlement patterns resulted from Ping River avulsions (Tongsa-ard, 1988). Presumably, as the Ping River avulsed across the Chiang Mai Basin, villages established wherever the river was active. Because villages then remained even as the Ping River avulsed elsewhere, palaeochannel planforms were preserved by elongated threads of villages that were originally built along the formerly active channels (Tongsa-ard, 1988).

Concurringly, some of these villages have names that allude to riverside locations (Figure 2a and Figure 2b) (Tongsa-ard, 1988; Teo, 2018). Thai village names traditionally reflect its surroundings by incorporating local landscape features. For example, Ban San Rim Ping means "Levee by the Ping River Village"; Ban Pa Phai means "Bamboo Forest Village" (Teo, 2018; Tongsa-ard, 1988). While the landscape may have changed since these villages were founded, many of the original village names remain. The most telling and common indicator of a riverside village are those with names that contain the word 'San' ('ridge' or 'levee' in the context of a floodplain), which tell that the village was built upon a levee (Tongsa-ard, 1988). As Figure 2a and Figure 2b show, many 'San' villages in the central area of the Basin are not located next to rivers existing today, but are consistent with palaeochannels suggested by settlement patterns. 


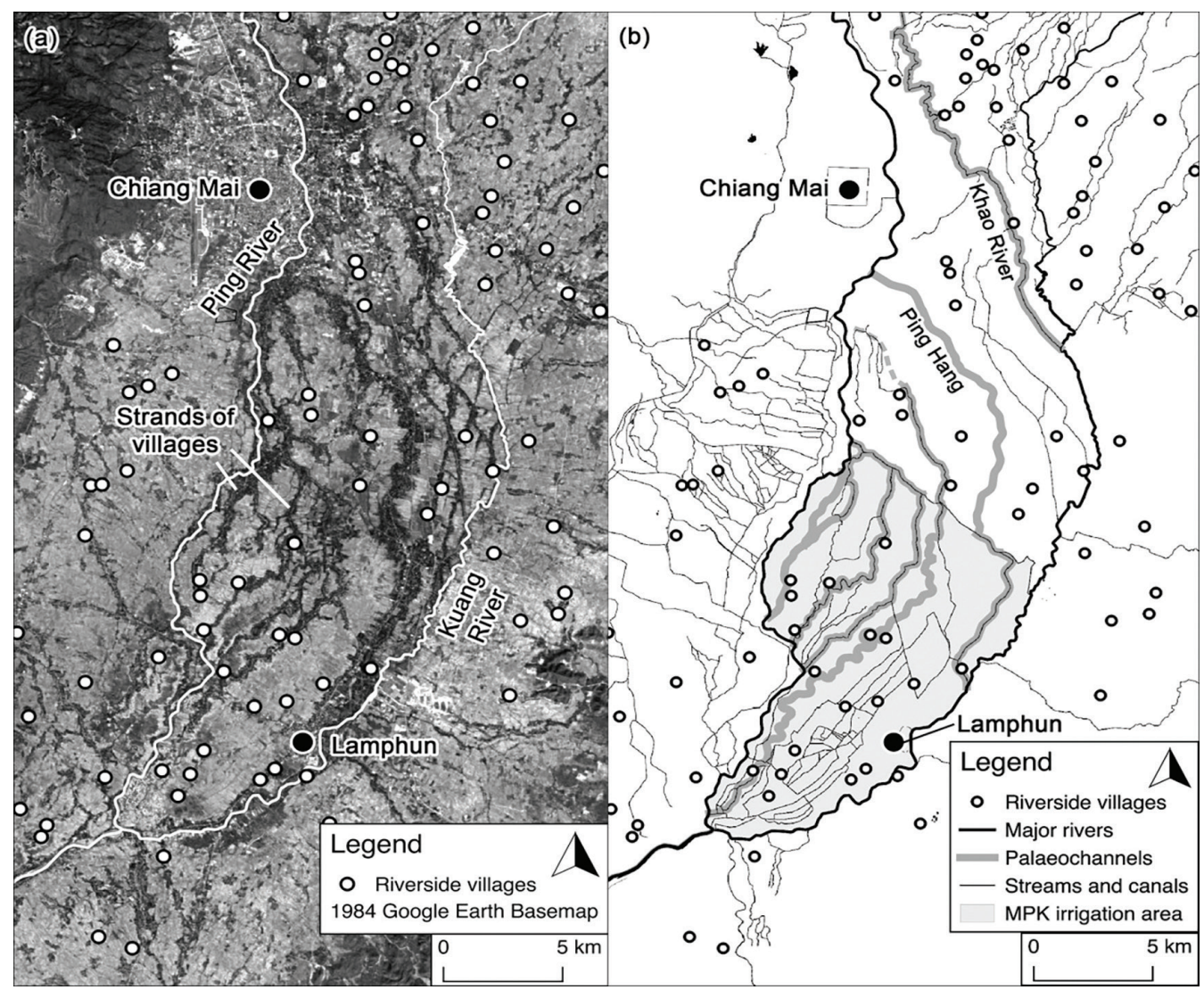

Figure 2. (a) Settlement patterns in the Chiang Mai Basin are easily observed through this aerial photograph captured in 1984 (converted into monochrome from original coloured Google Earth image; Google Earth, 2019). Dark grey to black areas are the result of dense tree vegetation (i.e. where villages are located), while light grey areas are cleared land converted into paddy fields. In the central area, there are multiple strands of villages with layouts reminiscent of meandering rivers. Even though these villages are not found next to rivers today, including the Ping and Kuang Rivers, some of these villages have names that allude to a riverbank location (see white circles). An index of these riverside villages is included in Appendix B. Riverside village names are as gathered by the author, based on maps published by Thailand's National Imagery and Mapping Agency (National Imagery and Mapping Agency, 1999a, 1999b 2007a, 2007b). (b) Palaeochannels (see thick grey lines) can be traced from settlement patterns, village names, and meandering irrigation canals. 
Palaeochannel planforms were further preserved by the conversion of palaeochannels into irrigation canals (Figure $3 \mathrm{a}$ and Figure $3 \mathrm{~b}$ ). For more than 1,000 years, Lanna communities installed communal irrigation networks, locally known as muang fai, to support large-scale wet-rice cultivation (Tongdeelert \& Lohmann, 1991; Surarerks, 2006; Mungsunti, 2013; McGrath et al., 2017). In the central area of the Chiang Mai Basin, villagers had apparently utilised palaeochannel surface depressions as readily-available streamflow conduits for their muang fai system (Tongsa-ard, 1988). These irrigation canals hence adopted the meandering planforms of the palaeochannels, contrasting the more angular pattern of additionally constructed irrigation canals (Figure $3 a$ and Figure $3 b$ ). It is unknown when this particular muang fai was first installed.

From the co-substantiating evidence between settlement patterns, topography (i.e. remnant levees, palaeochannel scars), village names and meandering irrigation canals, five palaeochannels are strongly suggested (Tongsa-ard, 1988). Named after their respective irrigation canals, these include the Muang Buak Khok, the Muang Mae Ping Noi, the Muang Lamphun (also known as the Muang Mae Ping Kao), the Muang Saen Yot, and the Khlong Mae Ping Hang (Figure 3a). Three of these palaeochannel-canals are even directly referred to as former Ping River channels by local name. Muang Mae Ping Noi means 'Little Ping River Canal'; Muang Mae Ping Kao means 'Old Ping River Canal'; Khlong Mae Ping Hang means 'Distant Ping River Canal' (Teo, 2018). All five palaeochannel-canals are now part of a large irrigation network named the Mae Ping Kao (MPK) Irrigation Project, a structurally upgraded version of the precursor muang fai network (Cohen \& Pearson, 1998; Lebel et al., 2010).

Since the writing of Tongsa-ard (1988), land use change and reorganisation of the MPK irrigation canal network has removed some of the evidences used by Tongsa-ard (1988) to identify these palaeochannels. Long sections of Muang Buak Khok and Muang Saen Yot canals have been filled in (Figure 3a). In its place, land has been developed or converted for agriculture. Meandering settlement patterns are also increasingly obscured by the expansion of villages, the re-planning of road infrastructure and the large-scale conversion of land into tree orchards. 


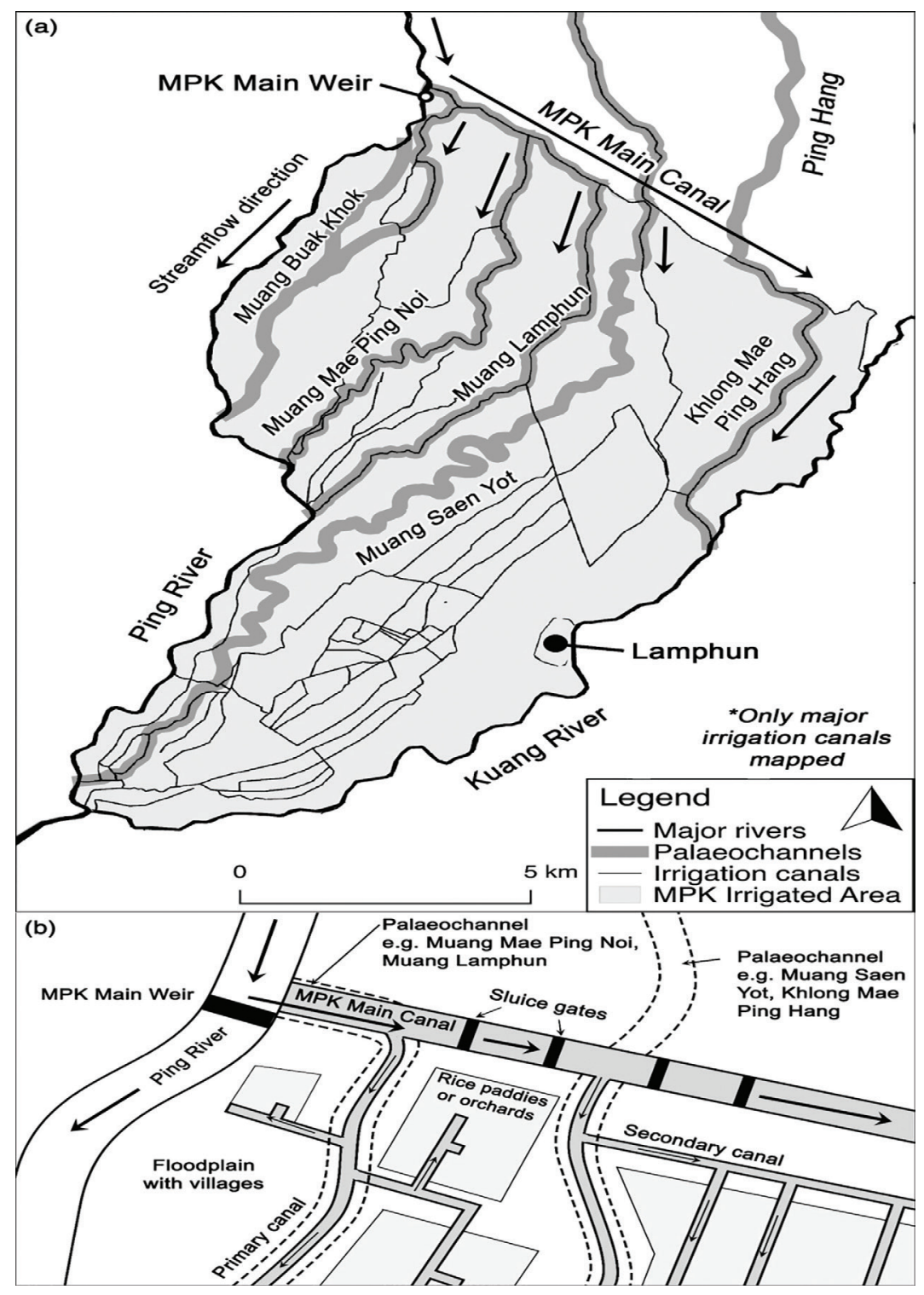

Figure 3. (a) Map of the Mae Ping Kao (MPK) Irrigation Project. Several irrigation canals of the network appear to be converted from sections of palaeochannels, thus adopting their meandering planforms. Palaeochannel planforms are adapted from Tongsa-ard (1988); the irrigation canal network mapped is as of 2017. (b) Simplified layout of the MPK Irrigation Project. Water is redirected from the Ping River into a network of canals that distribute water across a large area of land. Sluice gates and pumps control water flow. Artificially built canals are coloured grey. Water re-enters the Ping River further downstream. 


\section{Ping Hang palaeochannel}

Remaining avulsion research in the Chiang Mai Basin has focused on the Ping Hang palaeochannel ('Distant Ping') due to its association with Wiang Kum Kam, the formerly lost capital city of the Lanna Kingdom. The Ping Hang palaeochannel is $\sim 23 \mathrm{~km}$ long, extending from Wiang Kum Kam to Lamphun, and joining the present-day Kuang River (Figure 4). Evidence of the palaeochannel has been established by a combination of historical literature analysis and excavations at Wiang Kum Kam. Most of the Ping Hang palaeochannel currently does not contain water, as it has been artificially filled for construction. However, its planform is preserved by the Chiang MaiLamphun Road (106), which was built on the $\sim 5 \mathrm{~m}$ high alluvial ridge of the palaeochannel (Tongsa-ard, 1988). The southern $\sim 8.6 \mathrm{~km}$ of the palaeochannel has been converted into an irrigation canal (i.e. the Khlong Mae Ping Hang mentioned in the previous section; Teo, 2018). The Ping Hang palaeochannel is also known as the Ping Dum River ('Former Ping River' (Singharajwarapan et al., 2004).

Historical Thai literature. Most of Northern Thai history is remembered through legends, myths and stories anecdotally passed down from generation to generation (Van Beek, 1995; Promsao, 1996). Many of these tales were also recorded in palm leaf manuscripts, traditionally written in ancient script by Buddhist monks and archived in temples. More recently, universities and libraries have begun to preserve and translate these manuscripts (Digital Library of Northern Thai Manuscripts, 2019). While these manuscripts are often semihistorical due to injections with religious lore, locations of key places have little reason to be inaccurate.

In several key manuscripts, there are references to the Ping River and its former course along the Ping Hang palaeochannel (Teo, 2018). The Camadevivamsa Chronicle recounts the founding of the ancient Mon city of Hariphunchai in the mid- $6^{\text {th }}$ Century by Queen Camadevi. The construction of Hariphunchai completed in $768 \mathrm{CE}$, with Queen Camadevi arriving in Lamphun between 768-769 CE (Penth, 2004). Throughout the Camadevivamsa, several references are made to the Ping River (by its historical name, the Phing River) and its close vicinity to Hariphunchai and its capital city, Lamphun. Today, the Ping River is $\sim 6 \mathrm{~km}$ west of Lamphun (Figure 4). The following excerpts are as translated into English by Swearer and Premchit (1998): 
As Vasudeva was wandering about looking for a peaceful site, he saw the place where the Buddha's religion was once established. Thinking that this site was exceptionally secure, he built a city [Hariphunchai] there on the banks of the Ping River. (Swearer \& Premchit, 1998; p. 64)

The king sent his daughter, Camadevi, to rule the city [of Hariphunchai]. She boarded a boat together with a large retinue of five hundred men and five hundred venerable monks who knew the tipitaka [Buddhist scriptures]. Her journey up the river Ping [to Hariphunchai] took seven months. (Swearer \& Premchit, 1998; p. 64)

After passing through that place, they headed west and reached the Ping River. Then, realizing they were lost, they talked among themselves, 'Friends! Haripuñjaya [Hariphunchai] is located to the west of the river Ping. After crossing the river, we shall see Haripuñjaya. (Swearer \& Premchit, 1998; pp. 115-116)

Five hundred years after the founding of Hariphunchai, King Mengrai of the Lanna Kingdom conquered the city. A new capital city, Wiang Kum Kam, was built further north in 1286/87 CE (Figure 4). The following excerpt appears in both the Phongsawadan Yonok (translated into Thai by Prachakitkorachak, 1972) and the Chiang Mai Chronicle (translated into English by Wyatt \& Wichienkeeo, 1995):

In the rwai set year, s. 648 [1286/87 CE], King Mengrai moved to build Wiang Kum Kam. He built a moat around the city on all four sides, channelling the flowing waters of the Mae Raming [historical name of the Ping River]. He built a palisade on all four sides of the city, and had a great many dwellings and buildings constructed. (Wyatt \& Wichienkeeo, 1995; p. 57)

The Khlong Nirat Hariphunchai further indicated that Wiang Kum Kam was built on the western bank of the Ping River. This contradicts the location of the city's ruins today, which are east of the current Ping River (Figure 4). The Khlong Nirat Hariphunchai, written in ancient script, is an epic love poem written between the $14^{\text {th }}$ and $16^{\text {th }}$ Centuries (Lagirarde, 2004). The poem tells of the unknown poet's longing for his beloved while travelling from Chiang Mai to Lamphun. On the way, the poet explores Wiang Kum Kam and encounters a built canal (Stanza 49): 
(ฉบับเชียงใหม่)

อรรณพพระขวางขั้นขอบ
ผืนแผ่นสุยลงเลิง
คองเห็นที่รักเทิง
ยลอื่นสันเสี้ยนตั้ง

อรรณพพระขวางขั้นขอบ

ผืนแผ่นสุยลงเลิง

ยลอื่นสันเสี้ยนตั้ง

\author{
พิงเพิง รอดเอ่ \\ ลวดยั้ง \\ ใจเช่น ครานี \\ ตอกไว้วักษณ์เรียม
}

Stanza 49 as translated into Thai by Na Nagara (1973). An official English translation has not been published.

Na Nagara (1973) explains that the canal referred to in the poem was constructed to divert the Ping River from flowing towards the southeast (as does the Ping Hang) to the southwest (as does the present Ping River, which introduces one hypothesis that the avulsion was somehow affected by purposeful diversion attempts). Streamflow diversion was presumably attempted because Wiang Kum Kam suffered from persistent flooding (Van Beek, 1995; Ng et al., 2015). According to lore, initial flow diversion attempts were unsuccessful until the installation of a $19 \mathrm{~m}$ long reclining Buddha at Wat Phra Non Nong Phueng, as it was believed that the Buddha would be able to control the river flow (Tongsa-ard, 1988). While the temple was described to be next to the Ping River at a later section of the poem (Lagirarde, 2004), Wat Phra Non Nong Phueng is currently $\sim 3 \mathrm{~km}$ east of the present Ping River but indeed adjacent to the Ping Hang palaeochannel (Figure 4).

From these descriptions in Thai literature, it is ubiquitously accepted that the Ping River was following the course of the Ping Hang palaeochannel during the occupancy of Wiang Kum Kam (Tongsa-ard, 1988; Wyatt \& Wichienkeeo, 1995; Lagirarde, 2004; Singharajwarapan et al., 2004; Wood et al., 2004; Ng et al., 2015). However, a reference to the avulsion event has not been discovered within palm leaf manuscripts, which suggests that the Ping Hang avulsion may have occurred unwitnessed or without significant consequence, such as after Wiang Kum Kam was already deserted. 


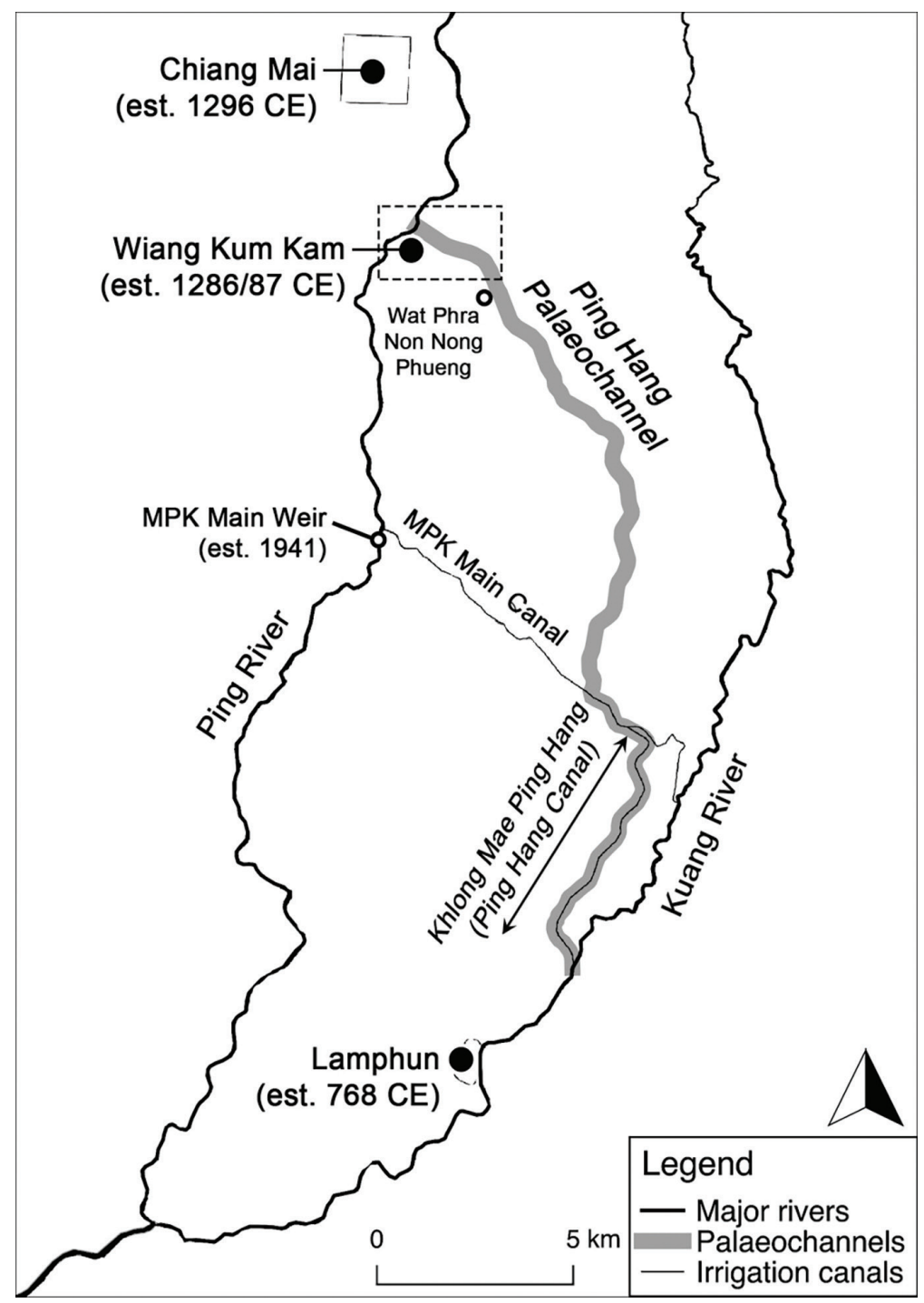

Figure 4. Map of the Ping Hang palaeochannel, a former course of the Ping River. The Ping Hang extends from Wiang Kum Kam, continuing south towards Lamphun - the southern section of the present Kuang River was previously a part of the Ping River. The Ping Hang's planform is preserved by the 106 Chiang Mai-Lamphun Road and an irrigation canal. During their respective occupancies, the cities of Lamphun and Wiang Kum Kam were historically described to be west of the Ping River. A larger map of the Wiang Kum Kam area (dashed box) is provided in Figure 5. 
Excavations at Wiang Kum Kam. In 1982, the Department of Fine Arts Unit 4 of Chiang Mai University discovered remnants of Wiang Kum Kam within the Chang Kham Village of the Tha Wang Tan subdistrict (Figure 5) (Velechovsky et al., 1987; Singharajwarapan et al., 2004). Previously, Wiang Kum Kam was only known through mentions in palm leaf manuscripts but its site and existence was unknown. As previously mentioned, King Mengrai built Wiang Kum Kam in 1286/87 CE as the capital of the Lanna Kingdom. However, after only five years of royal occupancy in Wiang Kum Kam, King Mengrai established Chiang Mai as the new capital in 1296 CE (Wyatt \& Wichienkeeo, 1995). Wiang Kum Kam remained as a satellite town of Chiang Mai, a residence for nobles and a defence outpost until it was finally deserted (Ongsakul, 2005).

Excavations at Wiang Kum Kam suggested that the migration of the Lanna capital city was spurred by recurrent flooding issues (Van Beek, 1995; Ng et al., 2015). Most structures in Wiang Kum Kam were buried by sandy flood and crevasse splay deposits, up to $\sim 2 \mathrm{~m}$ thick (Chumpol, 1987; Kanjana, 1987; Kriangkrai, 1987; Wood et al., 2004). Based on a thick layer of flood sediments, Velechovsky et al. (1987) proposed that a single large flood had led to the ultimate abandonment of the city, with cross-bedded sand consistent with flow coming from the north and northwest of the city. Wiang Kum Kam had apparently suffered particular flood damage as it was within a low-lying area of the floodplain (Singharajwarapan et al., 2004).

Sediment coring (Singharajwarapan et al., 2004; Uttamo, 2004; $\mathrm{Ng}$ et al., 2015) and electrical resistivity tomography (Hinz et al., 2010) revealed a length of subsurface coarse sand along the northeastern boundary of the ancient city, extending from the current Ping River and continuing southeast (Figure 5). This body of sand was interpreted as palaeochannel fill deposits of the Ping Hang, thus agreeing with mentions in Thai literature that Wiang Kum Kam was located on the western bank of the Ping River. The palaeochannel's existence is further supported by the orientation of several excavated temples that are oriented towards the Ping Hang (it is traditional for the entrance of temples to face a river), such as Wat Phya Mangrai (alternative spelling 'Wat Phra Mengrai'), Wat Phra Chao Ong Dum, Wat Nan Chang (also known as Wat Ping Hang) and Wat E-Kang (Figure 5) (Teo, 2018). 


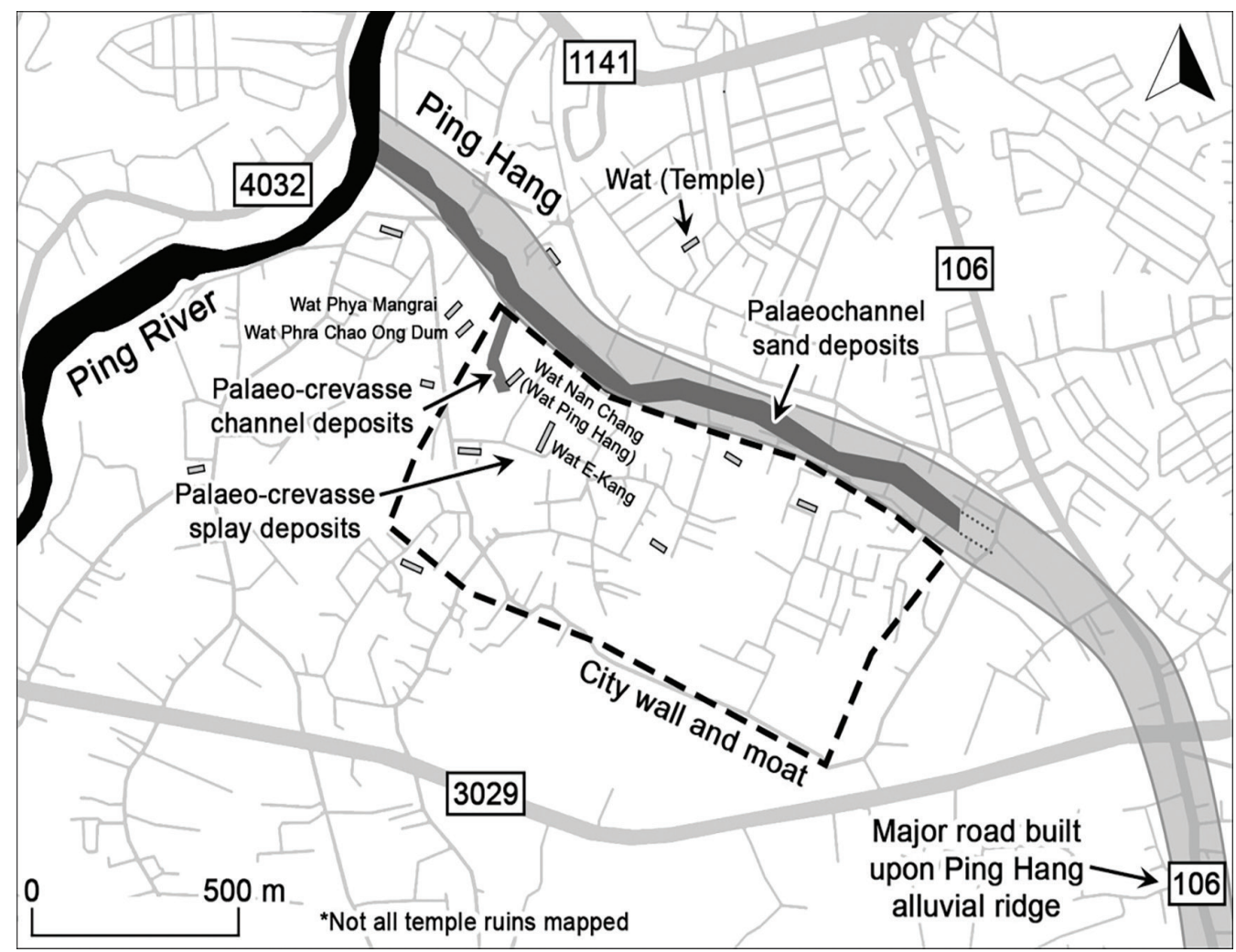

Figure 5. Map of the Wiang Kum Kam area. Palaeochannel deposits, discovered northeast of the city, appear to extend towards the Ping Hang alluvial ridge preserved by the 106 Chiang MaiLamphun Road. Several temple ruins are oriented pointing towards the palaeochannel. Excavated temples, including Wat Phra Mangrai, Wat Phra Chao Ong Dum, Wat Nan Chang (Wat Ping Hang) and Wat E-Kang were buried under thick layers of sandy flood and crevasse splay deposits.

Date estimates related to the Ping Hang. In separate historical texts, Hariphunchai/Lamphun were described to be west of the Ping River (the earliest mention during the founding of Hariphunchai in the mid- $6^{\text {th }}$ Century), and then also west of Wiang Kum Kam (the earliest mention during the founding of Wiang Kum Kam in the late $13^{\text {th }}$ Century). As both descriptions are consistent with the planform of the Ping Hang palaeochannel, one may assume that the Ping River was following the full Ping Hang course since the founding of Hariphunchai/Lamphun in the mid- $6^{\text {th }}$ Century (Tongsa-ard, 1988). 
However, this is not the only possible interpretation. Since the Ping River has experienced multiple segmental avulsions in the past, it should also be considered that the Ping River segment upstream of Hariphunchai/Lamphun might have been different during the founding of Hariphunchai than during the founding of Wiang Kum Kam. An alternative description is that the downstream section of the Ping Hang course was active during and perhaps earlier than the mid- $6^{\text {th }}$ Century, and the full Ping Hang course was active during and perhaps earlier than the late $13^{\text {th }}$ Century.

Across different sources of information, several dates are proposed for the 1) the abandonment of Wiang Kum Kam, 2) the floods that affected Wiang Kum Kam, and 3) the Ping Hang avulsion. It is tempting to treat these dates synonymously due to the prevailing hypotheses that Wiang Kum Kam was abandoned because of persistent flooding, and that a large flood had triggered the Ping Hang avulsion. To avoid circular reasoning, care is needed when referring to the dates of these process-connected but possibly time-separated events (e.g. the abandonment of Wiang Kum Kam did not necessarily coincide with the Ping Hang avulsion, but both events were likely related to floods). The following list summarises and explains the various date estimates related to the abandonment of Wiang Kum Kam and the Ping Hang.

- Wiang Kum Kam abandoned sometime between 1558 and 1774 CE. The 1558-1774 CE window was formed because mention of Wiang Kum Kam ceased during this period (Ongsakul, 1987). When the Burmese conquered Chiang Mai in $1558 \mathrm{CE}$, palm leaf manuscript documentation was paused and the written history of Wiang Kum Kam stopped. Wiang Kum Kam was not mentioned again when manuscript writing resumed. It is guessed that Wiang Kum Kam was abandoned soon after Burmese occupation, leaving the city to be buried by further floods (Ongsakul, 1987). Eventually, the area was resettled again, with a new village built above the buried lost city. The earliest record of resettlement in the area was in $1774 \mathrm{CE}$, when the name of the subdistrict 'Tha Wang Tan' (which encompasses the area of Wiang Kum Kam until today) first appeared in historical documents (Ongsakul, 1987). 
- Wiang Kum Kam abandoned sometime between 1527 and 1831 CE. From architectural styles and archaeological inscription, Velechovsky et al. (1987) determined that Wiang Kum Kam was abandoned in the early $16^{\text {th }}$ Century (est. post-1527 CE). The youngest excavated temple, Wat Nan Chang, is of early $16^{\text {th }}$ Century style and younger architectural styles are not found from other ruins (Velechovsky et al., 1987). Notably, the lack of Burmese influence suggested that the city was abandoned before or during early Burmese occupation in $1558 \mathrm{CE}$ ( $\mathrm{Ng}$ et al., 2015). Due to the discovery of a massive layer of flood deposits above the ruins, Velechovsky et al. (1987) proposed that a large flood had led to the ultimate abandonment of the city. As geochronological dating was not conducted then, the date of the large flood was speculated to be $1831 \mathrm{CE}$, because it is the year of a known catastrophic flood (Smith, 1873; Velechovsky et al., 1987; Tangtham et al., 1999).

- Ping Hang avulsion triggered by 1831 CE flood. The 1831 CE flood is known to be high magnitude (Smith, 1873; Tangtham et al., 1999). It was described in the Siam Repository:

In the Siamese Civil era 1193 [1831 CE]... there was a great inundation in the Kingdom of Siam. It prevailed in all quarters. At first there was excessive rainfall in the north [presumably Northern Thailand]. In the $11^{\text {th }}$ month of that year the water was so great that it covered the entire plains of the forests of the north to the depth of one and one and quarter fathoms [ 1 fathom $\approx 1.8 \mathrm{~m}$ ], rushing over them into the rivulets and streams, and it them overspread all the ricefields of the northern provinces to a depth of three quarters of a fathom, one fathom, one and quarter and one and a half fathoms, varying with the height of the land" (Smith, 1873, p. 373).

Though there is no record of this flood being related to the Ping Hang avulsion, the sheer magnitude of this flood led to some speculation that it may have triggered the avulsion (Velechovsky et al., 1987; Wood et al., 2004; Wood \& Ziegler, 2008). This speculation is disputed by geochronological dating conducted later by Ng et al. (2015). The $1831 \mathrm{CE}$ flood should still be considered as a possible trigger for other avulsions. 
- Ping Hang abandoned sometime between 1412 and 1552 CE, coinciding with a high-energy flood that occurred sometime between 1476 and 1512 CE. Luminescence dating of sediment from the top of the palaeochannel fill estimates that the palaeochannel was last active, and therefore abandoned, approximately between 1412 and $1552 \mathrm{CE}$ (see Figure 6 in Ng et al., 2015). Additional radiocarbon dating of nearby floodplain sediments indicate a high-energy flood that occurred between 1476 and $1512 \mathrm{CE}$ (attempts to manage persistent floods are also evident by a man-made dyke built after $1412 \pm 12 \mathrm{CE}$; Ng et al., 2015). As the 1476-1512 CE flood overlaps with the estimate of the Ping Hang's abandonment in 1412-1552 CE, it is implied that a flood had triggered the avulsion (Ng et al., 2015). $\mathrm{Ng}$ et al. (2015) also proposes that Wiang Kum Kam was abandoned as a result of the 1524-1525 CE catastrophic flood mentioned in the Chiang Mai Chronicle (Wyatt \&Wichienkeeo, 1995).

Overall, there are date overlaps between the estimates for the desertion of Wiang Kum Kam (early-mid $16^{\text {th }}$ Century, possibly around 1524-1525 CE), a large flood (after 1476-1512 according to radiocarbon dating), and the abandonment/avulsion of the Ping Hang (between 1412-1552 CE). Due to significant overlaps, the exact sequence can only be speculated. From the available information, a reasonable interpretation is that 1) persistent floods led to or highly influenced the desertion of Wiang Kum Kam, 2) these floods had perhaps setup the Ping Hang for an impending avulsion (e.g. high sediment loads, indicated by the thick flood deposits, may have increased channel instability through in-channel sedimentation and/or promoting channel aggradation), and 3) the Ping Hang avulsion then occurred after Wiang Kum Kam was already vacated (as implied by the lack of documentation of the event, including reports of damage and/or fatality) - all of these events occurring within the $15^{\text {th }}$ to the mid- $16^{\text {th }}$ Centuries.

\section{Khao River palaeochannel}

While no formal research has been conducted, the Khao River ('Old River') is also locally rumoured to be a palaeochannel, as evident by its name. Field observations and map analysis conducted by this author provide enough preliminary evidence to hypothesise that the Khao River, together with the present-day Kuang River, is another Ping River palaeochannel. However, significant channel re-engineering 
and land use change around both rivers has formed a drainage system that is highly modified from the original river channels. While channel modifications have distorted the natural course of the Khao and Kuang Rivers (involving the construction of diversion canals, the filling in of long river reaches, and the redistribution of streamflow into constructed small drains), their original courses can only just be discerned from map analysis and retracing river flow paths in the field (Teo, 2018).

As mapped by Thailand's National Imagery and Mapping Agency (National Imagery and Mapping Agency, 1999a, 1999b, 2007a, 2007b), and as also visible in Google Maps/Earth (Google, 2019), a long segment of the Kuang River is 'missing'. From the Kuang River Reservoir, the Kuang River initially flows southwest towards Chiang Mai, along with the other streams of the Kuang River Alluvial Fan (Figure 6). However, $3 \mathrm{~km}$ before the toe of the alluvial fan, the Kuang River abruptly ends at Ban Mae Kow ('Khao River Village'). The Kuang River then abruptly begins again $10 \mathrm{~km}$ away. However, streamflow between these two separate segments of the Kuang River are still connected via a complicated network of drains and an artificial canal named the Rong Pla Khao (13.6 km long). It is obvious that the two segments of the Kuang River were originally connected via the Khao River (Figure 6). For a currently unknown reason, the Khao River was then purposefully abandoned and streamflow was redirected through an artificial canal - perhaps to shift flow from the alluvial fan away from urban development expanding from Chiang Mai in the west.

The Khao River also shows signs of heavy modification. First, the upper Khao River is also 'missing', abruptly beginning at the confluence of two artificial canals near the village of Ban Morakot (Google, 2019; National Imagery and Mapping Agency, 2007a, 2007b). The northern canal, Mae Nong Han, is an irrigation canal ( 5-10 m wide) that extends from Mae Faek, a tributary of the Ping River (Figure 6). Certain stretches of the Mae Nong Han are also sinuous, implying that it also used to be a natural river. On the northern bank of the Mae Faek, there is an unnamed, but known, Ping River palaeochannel that connects to the Mae Nong Han. It is apparent that this unnamed Ping River palaeochannel, the Mae Nong Han, the Khao River and the Kuang River were once a single continuous river (Figure 1 and Figure 6). Similarly to how the Ping River currently flows along the western margin of the Basin, this river composite of the aforementioned channels flowed along the eastern margin of the Basin (Figure 1). 
Second, the Khao River's form alters dramatically throughout its course. The northern half of the defined Khao River is a meandering river, ranging between $15-25 \mathrm{~m}$ wide and is sinuous along certain lengths (Figure 6). However, as the Khao River flows further south into increasingly developed and urban areas, the natural channel ends and streamflow is instead divided into a complex network of small concrete drains ( 1-2 m wide) interspersed between and under a large suburban area. It is evident that the lower half of the Khao River has been filled in for development, and incoming streamflow has been distributed through these drains. Nevertheless, the original course of the Khao River can still be somewhat traced, as one of the small drains is still mapped as the Khao River (National Imagery and Mapping Agency, 2007a, 2007b; Google, 2019). The said Khao River Drain ends just $400 \mathrm{~m}$ away from the Kuang River, and flow enters an undisturbed segment of the Khao River palaeochannel. The water then drains into the Kuang River - after Khao River streamflow had been distributed across the multiple canals and drains, the flow volume of the Khao River Drain is significantly lower than the upper Khao River's. It is not known when the channel reengineering of the Khao and Kuang Rivers were conducted, as records of these projects have yet to be located. While the artificial canal connecting the Kuang Rivers already appears in 1984 Google Earth imagery (Google Earth, 2019) and a map published also in 1984 (Lumpaopong et al., 1984), it is possible that the canal is significantly older. The Chiang Mai Basin has a long history of artificial canal construction. For example, the earliest record of major river engineering was in 1277-1280 CE, when a $36 \mathrm{~km}$ long irrigation canal (the $\mathrm{Ai} F a$ Canal) was constructed to divert water from the Ping River (Wyatt \& Wichienkeeo, 1995; Penth, 2004). 


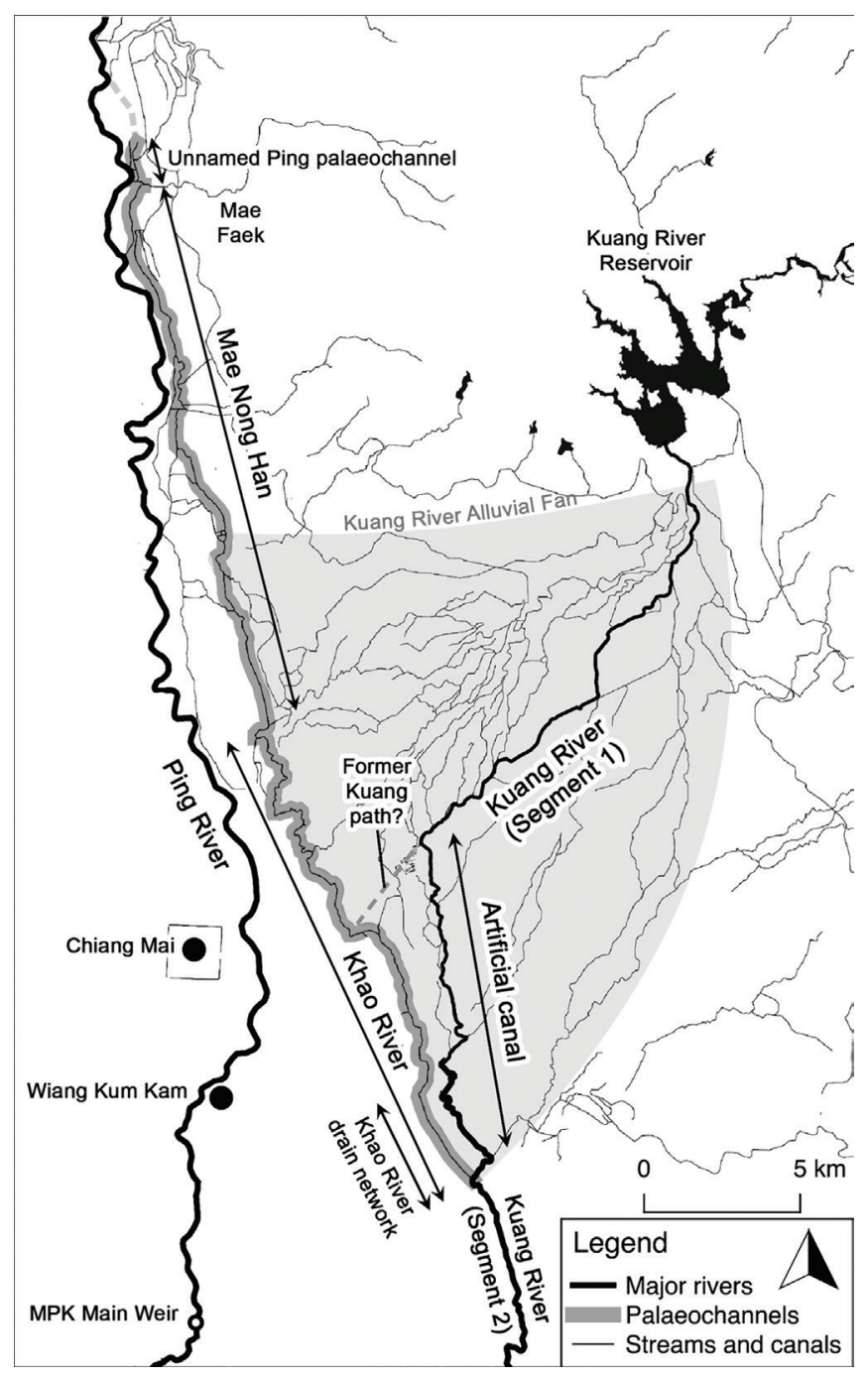

Figure 6. Map of the Khao River palaeochannel, a former course of the Ping River. It is apparent that the Khao River was previously a section of the Kuang River that was abandoned when flow was redirected through an artificial canal - thus the naming of the abandoned reach as 'Khao River', meaning 'Old River'. The upper section of the Khao River is 'missing' but its full planform is suggested by its continuous connection with the Mae Nong Han canal and a Ping River palaeochannel. At the southern end of the Khao River, streamflow is distributed through a complex network of small drains built to accommodate suburban growth over the palaeochannel. 


\section{DISCUSSION}

Overall, the information gathered in this paper is useful to the continued future study of avulsions in the Chiang Mai Basin because it combines research that have focused on different palaeochannels, merges information from multidisciplinary source materials, reconciles possible language barriers since sources are published in different languages (i.e. Thai, English and French, also with mixed transliteration and Romanisation practices of Thai script), and updates older research with recent findings.

Gathered across previous research, there are six possible Ping River palaeochannels - the Muang Buak Khok, the Muang Mae Ping Noi, the Muang Saen Yot, the Muang Lamphun, the Ping Hang, and the Khao River (Figure 1). Due to interest in Wiang Kum Kam, most palaeochannel research has focused upon the Ping Hang. Comparatively, very little is known about the other palaeochannels. Most distinctively, palaeochannels other than the Ping Hang were not excavated in previous studies (this author's own excavation results of other palaeochannels are currently being finalised). Palaeochannels other than the Ping Hang were largely identified from 'surface evidence', including settlement patterns, planform appearance, and written/oral history - such evidence is problematic. First, the Basin has a long and intensifying record of major river engineering works, artificial channel construction and land use change (Wyatt \& Wichienkeeo, 1995; Penth, 2004; Lebel et al., 2010), which intrinsically casts uncertainty upon any observation made from the surface appearance of channels. It is also entirely possible that modifications to the Basin's surface have removed surface evidence of more palaeochannels other than the six currently identified. Second, oral history is diminished and unreliable, as an avulsion has not occurred within living memory (Teo, 2018). Third, written documentation of avulsions has not been discovered - even if they were, reliable information would be limited. It is also possible for aspects of historical manuscripts to be fictionalised, especially in palm leaf manuscripts (Lagirarde, 2004; Trimble, 2012; Kirigaya, 2014).

With the exception of the Ping Hang (first mentioned in the mid- $6^{\text {th }}$ Century, and abandoned approximately between 1412-1552 CE; $\mathrm{Ng}$ et al., 2015), there is little available information that indicate the ages of the other palaeochannels, and when their respective avulsions occurred. On one hand, general hypotheses can be made. First, it is reasonable to hypothesise that the other palaeochannel-canals (the 
Muang Buak Khok, the Muang Mae Ping Noi, the Muang Saen Yot, and the Muang Lamphun) are younger than the Ping Hang, due to their strong influence on present-day settlement patterns (Figure 2; note that this hypothesis suggests that five avulsions have occurred within the past 500 years). Second, the positioning of the palaeochannels (Figure 1) suggests a westward succession of avulsions across the Chiang Mai Basin towards the present-day Ping River, which supports the hypothesis that the palaeochannel-canals are younger than the Ping Hang, and makes the suggestion that the Khao River is the oldest palaeochannel.

On the other hand, more precise ages are still important. Ages are needed to establish if the palaeochannels co-existed (e.g. as an anastomosing river), or if they had individually succeeded one another. While the latter is assumed by previous research and is suggested by the names of the palaeochannels (i.e. implying each to individually be former Ping River courses), there has been no other evidence to confirm this (e.g. maps, written documentation or sediment chronological evidence).

Knowing the ages of these palaeochannels may also aid in determining the events and processes that have setup and triggered avulsions (Stouthamer \& Berendsen, 2007). Overall, there are three mechanisms hypothesised to be involved in avulsion development in the Chiang Mai Basin - floods, earthquakes and human interference. These three factors are dominant fluvial drivers in the Chiang Mai Basin system - the Basin experiences frequent flooding (Wood \& Ziegler, 2008; Lim \& Boochabun, 2012; Ramdzan, 2016), experiences frequent low-to-moderate earthquakes (Fenton et al., 2003; Noisagool et al., 2016), and has a long history of channel engineering (Wyatt \& Wichienkeeo, 1995; Penth, 2004; Lebel et al., 2010). Evidence of avulsion development is only available from Ping Hang research, which concluded that the Ping Hang avulsion was triggered by a flood (Velechovsky et al., 1987; Uttamo, 2004; $\mathrm{Ng}$ et al., 2015). However, this does not definitively conclude the triggers of other avulsions. No similar research has been conducted to ascertain the mechanisms of other avulsions.

Human interferences must be acknowledged as a potential avulsion mechanism and during palaeochannel interpretation. There is a long history of channel modification in Thailand. Rivers have been long regarded as unpredictable - nature was 'always changing character, always altering course', cultivating a desire to manage 
and 'tame' rivers after centuries of suffering its ravages (Van Beek, 1995). At Wiang Kum Kam (translating to 'fortified town that controls the water' from Northern Thai), attempts at controlling the Ping Hang is evident from artificially raised levees and an excess streamflow diversion canal that is suspected to be the channel breach site of the Ping Hang avulsion (Na Nagara, 1973; Tongsa-ard, 1988; Van Beek, 1995; Lagirarde, 2004; Penth, 2004; Ng et al., 2015).

\section{CONCLUSION}

Past research on palaeochannels in the Chiang Mai Basin provides an extremely useful knowledge base to direct future palaeochannel/ avulsion research. Six palaeochannels have been identified, and research on the Ping Hang palaeochannel provides insight to the mechanisms involved in avulsion development. However, there are still significant uncertainties and knowledge gaps. This is due to three main issues: 1) intense basin surface modification casts inherent uncertainty upon any observation made from the Basin surface, 2) the ages of the palaeochannels are unknown, and 3) the mechanisms of one avulsion event (i.e. the Ping Hang avulsion) may not be transferable to other avulsions. Fundamental information for river/disaster management applications, such as avulsion frequency and avulsion mechanisms, has yet to be sufficiently resolved.

Moving forward, these uncertainties and knowledge gaps need to be addressed. However, 'surface evidence', including settlement patterns, planform appearance, and written/oral history, appear to be exhausted. Therefore, it is recommended that the subsurface be explored. As demonstrated by Ping Hang research, a sedimentologybased study will be able to provide invaluable information. Subsurface sedimentological evidence is deemed advantageous for several reasons, including 1) it directly detects physical remnants of past fluvial systems that can also be dated, 2) it is able to reveal histories beyond human observation and record, 3) it is able to identify older palaeochannels with no obvious surface manifestation, and 4) it is able to confirm if hypothesised palaeochannels were naturally formed or constructed. 


\section{ACKNOWLEDGEMENTS}

Special thanks to Professor Spencer Wood for sharing and helping locate key resources. Special thanks to Professor Fongsaward Singharajwarapan and Professor Sampan Singharajwarapan for their help and hospitality during my research in Chiang Mai. Thanks to Professor Robert Wasson, Professor Alan Ziegler and Professor David Taylor for reviewing early drafts of this manuscript.

\section{REFERENCES}

Allen, J.R.L. (1965). A review of the origin and characteristics of recent alluvial sediments. Sedimentology, 5(2): 89-191. https://doi.org/ 10.1111/j.1365-3091.1965.tb01561.x

Bridge, J., \& Leeder, M. (1979). A simulation model of alluvial stratigraphy. Sedimentolog, 26: 617-644. https://doi.org/10.1111/ j.1365-3091.1979.tb00935.x

Carling, P., Jansen, J., \& Meshkova, L. (2014). Multichannel rivers: their definition and classification. Earth Surface Processes and Landforms, 39: 26-37. https:// doi.org/10.1002/esp.3419

Chakraborty, T., Kar, R., Ghosh, P., \& Basu, S. (2010). Kosi megafan: Historical records, geomorphology and the recent avulsion of the Kosi River. Quaternary International, 227: 143-160. https:/ / doi.org/10.1016/j.quaint.2009.12.002

Chumpol, W. (1987). Grain size distribution in alluvial sediments around Wat Ee Kang at Wiang Kum Kam Thawang Tarn village, Amphoe Saraphi Changwat Chiang Mai. Chiang Mai University, Thailand.

Cohen, P.T., \& Pearson, R.E. (1998). Communal irrigation, state, and capital in the Chiang Mai valley (Northern Thailand): Twentiethcentury transformations. Journal of Southeast Asian Studies, 29(1): 86-110. https:// doi.org/10.1017/S0022463400021494

Digital Library of Northern Thai Manuscripts. (2019). Northern Thai literary tradition. Retrieved from http://lannamanuscripts.net/ en/about

Fenton, C.H., Charusiri, P., \& Wood, S.H. (2003). Recent paleoseismic investigations in Northern and Western Thailand. Annals of Geophysics, 46(5): 957-981. 
Google. (2019). Chiang Mai map. Retrieved from https://www. google.com/maps/@18.7586401,99.0449997,10.87z

Google Earth V 7.3.2.5491. (2019). Chiang Mai, Thailand (image from 31 December 1984; cited 29 January 2019). 18²'21.83"N, $98^{\circ} 58^{\prime} 54.18^{\prime \prime}$ E, Eye alt $53.58 \mathrm{~km}$. Landsat/Copernicus. Retrieved from https://www.google.com/earth/

Hinz, E.A., Liberty, L.M., Wood, S.H., Singharajawarapan, F., Udphuay, S., Paiyarom, A., \& Shragge, J. (2010). Student-based archaeological geophysics in northern Thailand. In: SEG technical program expanded abstracts 2010. (pp.3848-3852). Denver, USA. https:/ / doi.org/10.1190/1.3513651

Jones, L., \& Schumm, S. (1999). Causes of avulsion: an overview. In: Smith, N.D., \& Rogers, J. (Eds.), Fluvial sedimentology VI: Special publication of the international association of sedimentologists 28 (pp.171-178). Oxford: Blackwell Science.

Kanjana, K. (1987). Grain size distribution in alluvial sediments around Wat Ee Kang at Wiang Kum Kam Thawang Tarn village, Amphoe Saraphi Changwat Chiang Mai. Chiang Mai University, Thailand.

Kirigaya, K. (2014). Some annotations to the Chiang Mai chronicle: The era of Burmese rule in Lan Na. Journal of the Siam Society, 102: 9-10.

Kleinhans, M.G., Jagers, H.R.A., Mosselman, E, \& Sloff, C.J. (2008). Bifurcation dynamics and avulsion duration in meandering rivers by one-dimensional and three-dimensional models. Water Resources Research, 44(W08454): 1-31. https://doi.org/10.1029/ 2007WR005912

Kriangkrai, M. (1987). Grain size distribution in alluvial sediments around Wat Ee Kang at Wiang Kum Kam Thawang Tarn village, Amphoe Saraphi Changwat Chiang Mai. Chiang Mai University, Thailand.

Lagirarde, F. (2004). Un pèlerinage bouddhique au Lanna entre le XVIe et le XVIIe siècle d'après le Khlong Nirat Hariphunchai. Aséanie, 14: 69-107.

Lebel, L., Garden, P., Subsin, N., \& Nan, S.N. (2010). Averted crises, contested transitions: water management in the Upper Ping River basin, northern Thailand. In: Huitema, D., \& Meijerink, S. (Eds.). Water policy entrepreneurs: A research companion to water transitions around the globe (pp.137-157). Cheltenham, UK: Northampton, MA, USA: Edward Elgar Publishing. 
Lim, H.S., \& Boochabun, K. (2012). Flood generation during the SW monsoon season in northern Thailand. In: Terry, J., \& Goff , J. (Eds.). Natural hazards in the Asia-Pacific region: Recent advances and emerging concepts (pp.7-20). Geological Society Special Publications 361.

Lim, H.S., Boochabun, K., \& Ziegler, A.D. (2012). Modifiers and amplifiers of high and low flows on the Ping River in northern Thailand (1921-2009): The roles of climatic events and anthropogenic activity. Water Resources Management, 26(14): 4203-4224. https:/ / doi.org/10.1007/s11269-012-0140-z

Lumpaopong, B., Pinthong, J., Chalothon, C., \& Kaida, Y. (1984). Chiang Mai-Lamphun valley, Thailand (Asian rice-land inventory: A descriptive atlas, no. 2). Center for Southeast Asian Studies, Kyoto University, Kyoto, Japan.

Macdonald, A.S., Barr, S.M., Dunning, G.R., \& Yaowanoiyothin, W. (1993). The Doi Inthanon metamorphic core complex in NW Thailand: Age and tectonic significance. Journal of Southeast Asian Earth Sciences, 8(1-4): 117-125. https://doi.org/10.1016/ 0743-9547(93)90013-F

Makaske, B. (2001). Anastomosing rivers: a review of their classification, origin and sedimentary products. Earth-Science Reviews, 53: 149-196. https://doi.org/10.1016/S0012-8252(00)00038-6

Margane, A., \& Tatong, T. (1999). Aspects of the hydrogeology of the Chiang Mai-Lamphun Basin, Thailand that are important for the groundwater management. Zeitschrift für Angevandte Geologie, 45: 188-197.

McGrath, B., Sangawongse, S., Thaikatoo, D., \& Corte, M.B. (2017). The architecture of the metacity: Land use change, patch dynamics and urban form in Chiang Mai, Thailand. Urban Planning, 2(1): 53-71. https://doi.org/10.17645/up.v2i1.869

Mungsunti, A. (2013). 'Muang Fai' irrigation system in northern Thailand: Farming productivity and water use efficiency. Economy and Environment Program for Southeast Asia (EEPSEA). Laguna, Philippines.

Na Nagara, P. (1973). Khlong Nirat Hariphunchai, modern Thai edition and translation by Prasert na Nagara (in Thai) ( $3^{\text {rd }}$ ed.). From the manuscripts kept in Chiang Mai and the National Library in Bangkok, Thailand. 
National Imagery and Mapping Agency. (1999a). Changwat Chiang Mai, Thailand, sheet 4746 I L7018 (Edition 1-RTSD), 1: 50,000. Bangkok: Royal Thai Survey Department. . (1999b). Amphoe San Pa Tong, Thailand, sheet 4746 II L7018 (Edition 1-RTSD), 1: 50,000. Bangkok: Royal Thai Survey Department.

. (2007a). Amphoe San Sai, Thailand, sheet 4846 IV L7018 (Edition 2-RTSD), 1: 50,000. Bangkok: Royal Thai Survey Department.

(2007b). Changwat Lamphun, Thailand, sheet 4846 III L7018 (Edition 2-RTSD), 1: 50,000. Bangkok: Royal Thai Survey Department.

Ng, S., Wood, S.H., \& Ziegler, A.D. (2015). Ancient floods, modern hazards: the Ping River, paleofloods and the 'lost city' of Wiang Kum Kam. Natural Hazards, 75: 2247-2263. https://doi.org/ 10.1007/s11069-014-1426-7

Noisagool, S., Boonchaisuk, S., Pornsopin, P., \& Siripunvaraporn, W. (2016). The regional moment tensor of the 5 May 2014 Chiang Rai earthquake $(\mathrm{Mw}=6.5)$, Northern Thailand, with its aftershocks and its implication to the stress and the instability of the Phayao Fault Zone. Journal of Asian Earth Sciences, 127: 231-245. https:// doi.org/10.1016/j.jseaes.2016.06.008

Ongsakul, S. (1987). Wiang Kum Kam (in Thai). In: Proceedings of the Seminar of Historical Sites in Chiang Mai. Chiang Mai: United College of Lanna Teachers Chiang Mai. . (2005). History of Lanna. Chiang Mai: Silkworm Books.

Penth, H. (2004). A brief history of Lan Na: Northern Thailand from past to present. Chiang Mai: Silkworm Books.

Phillips, J.D. (2011). Universal and local controls of avulsions in southeast Texas Rivers. Geomorphology, 130: 17-28. https:// doi.org/10.1016/j.geomorph.2010.10.001

Prachakitkorachak, P. (1972). Phongsawadan Yonok [Yonok chronicle] (in Thai) $\left(6^{\text {th }}\right.$ ed.) Bangkok: Phraephittaya.

Promsao, K. (1996). Chiang Mai: Seven hundred years. Chiang Mai: Within Books.

Qian, N. (1990). Fluvial processes in the lower Yellow River after levee breaching at Tongwaxiang in 1855. International Journal of Sediment Research, 5: 1-13. 
Ramdzan, K.N.B.M. (2016). Application of palaeoflood sedimentology to identify changes to the fluvial environments and to reconstruct peak discharges in the upper Ping River, Chiang Mai (Master's thesis). National University of Singapore. Singapore. Singharajwarapan, S., Suttmo, V., \& Singharajwarapan, F.S. (2004). Study of sedimentation in the ancient city of Wiang Kum Kam, Chiang Mai (in Thai). Department of Geology, Faculty of Science, Chiang Mai University, Thailand.

Sinha, R. (2009). The Great avulsion of Kosi on 18 August 2008. Current Science, 97(3): 429-433.

Slingerland, R., \& Smith, N.D. (2004). River avulsions and their deposits. Annual Review of Earth and Planetary Sciences, 32: 257-285. https:/ / doi.org/10.1146/ annurev.earth.32.101802.120201

Smith, S.J. (1873). The great inundation of Siam. Siam Repository (pp. 373-374).

Srisaka, V. (1989). Traditional Thai villages and cities: An overview. In: Culture and environment in Thailand: A symposium of the Siam society (pp.359-370). Bangkok: Siam Society.

Stouthamer, E., \& Berendsen, H.J.A. (2007). Avulsion: The relative roles of autogenic and allogenic processes. Sedimentary Geology, 198: 309-325. https:/ / doi.org/10.1016/j.sedgeo.2007.01.017

Surarerks, V. (2006). Muang Fai communities in Northern Thailand: People's experiences and wisdom in irrigation management. Journal of Developments in Sustainable Agriculture, 1: 44-52. https:// doi.org/10.11178/jdsa.1.44

Swearer, D.K., \& Premchit, S. (1998). The legend of Queen Cama: Bodhiramsi's Camadevivamsa, a translation and commentary. Albany, New York: State University of New York Press.

Syvitski, J.P.M., \& Brakenridge, G.R. (2013). Causation and avoidance of catastrophic flooding along the Indus River, Pakistan. GSA Today, 23(1): 4-10. https://doi.org/10.1130/GSATG165A.1

Tangtham, N., Tantasirin, C., \& Techamahasarononi, J. (1999). Floods and droughts of the lower Chao Phraya River Basin in relation to ENSO events and land use/land cover changes. In: Workshop on GAME-T. Kanchanaburi, Thailand.

Teo, E.A. (2018). Fluvial change the development of the Ping river, Thailand: sedimentological and chronological evidence (Doctoral dissertation). National University of Singapore. Singapore. 
Tongdeelert, C., \& Lohmann, L. (1991). The Muang Fai irrigation system of Northern Thailand. The Ecologist, 21(2): 101-106.

Tongsa-ard, S. 1988. The Study of Mae Ping River's old channel traces in Chiang Mai-Lamphun Basin (in Thai) (Master's thesis). Chiang Mai University. Thailand.

Trimble, S.W. (2012). Historical sources and watershed evolution. Philosophical Transactions of the Royal Society A: Mathematical, Physical and Engineering Sciences, 370(1966): 2075-2092.

Uttamo, W. (2004). Sedimentation study at Wiang Kum Kam, Saraphi District, Chiang Mai (in Thai) (Master's thesis). Chiang Mai University. Thailand.

Van Beek, S. (1995). The Chao Phya: River in transition. New York: Oxford University Press.

Velechovsky, M., Sinthusan, A., \& Pitragool, S. (1987). Geological aspects of the burial by flood of the ancient city of Wiang Kum Kam, Chiang Mai, Thailand. Center for the Promotion of Arts and Culture, Chiang Mai University.

Wood, S.H., Liberty, L.M., Singharajwarapan, F.S., Bundarnsin, T., \& Rothwell, E. (2004). Feasibility of gradient magnetometer surveys of buried brick structures at $13^{\text {th }}$ Century (CE) Wiang Kum Kam, Chiang Mai Province, Thailand. In: International Conference of Applied Geophysics (pp.22-30). Chiang Mai, Thailand.

Wood, S.H., \& Ziegler, A.D. (2008). Floodplain sediment from a 100year-recurrence flood in 2005 of the Ping River in northern Thailand. Hydrology and Earth System Sciences, 12: 959-973.

Wyatt, D.K., \& Wichienkeeo, A. (1995). The Chiang Mai chronicle. Chiang Mai: Silkworm Books. 


\section{APPENDIX A}

\section{Translations}

\begin{tabular}{|c|c|}
\hline Translation/Romanisation & Thai text \\
\hline \multicolumn{2}{|l|}{ Important river and palaeochannel names } \\
\hline Ping River (Mae Nam Ping) & แม่น้ำปิง \\
\hline Phing River & แม่น้ำพิงค์ \\
\hline \multicolumn{2}{|c|}{ (Historical name of Ping River e.g. in Camadevivamsa Chronicle) } \\
\hline Raming River & แม่น้ำระมิงค์ \\
\hline \multicolumn{2}{|c|}{$\begin{array}{l}\text { (Historical name of the Ping River e.g. in Phongsawadan Yonok } \\
\text { Chronicle) }\end{array}$} \\
\hline Kuang River (Mae Nam Kuang) & แม่น้ำกวง \\
\hline \multicolumn{2}{|l|}{$\begin{array}{l}\text { Ping Hang palaeochannel (Rong Roi Ping ร่อ } \\
\text { Hang) }\end{array}$} \\
\hline $\begin{array}{l}\text { Ping Dum River (alternative name of the } \\
\text { Ping Hang) }\end{array}$ & แม่น้ำปิงเดิม \\
\hline $\begin{array}{l}\text { Khao River (Mae Nam Khao), sometimes } \\
\text { spelled 'Kow' }\end{array}$ & แม่น้ำคาว \\
\hline Khlong Mae Ping Hang & คลองแม่ปิงห่าง \\
\hline Muang Buak Khok & เหมืองบวกครก \\
\hline Muang Saen Yot & เหมืองแสนยศ \\
\hline Muang Mae Ping Noi & เหมืองแม่ปิงน้อย \\
\hline Muang Lamphun (Muang Mae Ping Kao) & เหมืองลำพูน (เหมืองแม่ปิงเก่า) \\
\hline Mae Nong Han & แม่หนองหาน \\
\hline Communal irrigation system (muang fai) & เหมืองฝาย \\
\hline \multicolumn{2}{|l|}{ Important village and place names } \\
\hline \multicolumn{2}{|l|}{$\begin{array}{l}\text { Wat Phra Non Nong Phueng (Wat Nong } \\
\text { Phueng) }\end{array}$} \\
\hline Hariphunchai & หริภุญไชย \\
\hline Ban Mae Kow & บ้านแม่คาว \\
\hline Ban Morakot & บ้านมรกต \\
\hline Chang Kham Village & บ้านชั่งคำ \\
\hline Rong Pla Khaw & รองปลาขาว \\
\hline
\end{tabular}




\section{APPENDIX A (Cont.)}

\section{Translations}

\section{Translation/Romanisation}

Important village and place names

Tha Wang Tan

Historical Thai literature titles

Camadevivamsa Chronicle

('Chronicle of the Lineage of Camadevi')

Khlong Nirat Hariphunchai

Jinakalamali Chronicle

('The Sheaf of Garlands of the Epochs of the

Conqueror')

Phongsawadan Yonok Chronicle

Tamnan Nang Cammatewi

Wat Nong Pheung Chronicle

\section{Thai text}

ตำบลท่าวังตาล

ตำนานจามเทวีวงศ์

โคลงนิราศหริภุญไชย

ชินกาลมาลีปกรณ์

พงศาวดารโยนก

ตำนานนางจามเทวี

ตำนานวัดหนองผึ้ง 